\title{
SISTEM INFORMASI AKADEMIK SEKOLAH BERBASIS WEB PADA MADRASAH TSANAWIYAH (MTs) MIFTAHUL ULUM JRAGUNG
}

\author{
Muhammad Zaenur Rohman \\ Mahasiswa Program Studi Teknik Informatika Fakultas Teknik Universitas Wahid Hasyim \\ Jl. Menoreh tengah X/22 Sampangan Semarang 50236 \\ Email: Zaenurrohman1234@gmail.com
}

\begin{abstract}
Abstrak
Instansi baik milik pemerintah maupun swasta saat ini tidak akan lepas dari penggunaan Teknologi Informasi. MTs Miftahul Ulum Jragung merupakan salah satu instansi pendidikan setingkat Sekolah Menengah Pertama (SMP) yang ada di Desa Jragung Kecamatan Karangawen Kabupaten Demak. Namun, sistem pengelolaan data dan penginformasian data akademik yang berjalan masih dilakukan secara manual sehingga akan memunculkan masalah efisiensi waktu dalam pengelolaan dan penginformasiaannya. Penelitian ini ditujukan untuk membuat Sistem Informasi Akademik untuk membantu dalam pengelolaan data akademik serta mempermudah dalam proses penginformasiannya. Di samping itu untuk mempermudah pencarian data, sistem juga dilengkapi metode pencarian berdasarkan algoritma sequential search dimana algoritma ini merupakan algoritma yang paling sederhana dan mudah di aplikasikan. Pengembangan sistem ini menggunakan metode prototype, dimana langkahnya dimulai dengan analisis kebutuhan sistem, dilanjutkan pengumpulan bahan, desain, pembuatan, pengujian (desain ulang jika belum sesuai) dan pengaplikasian sistem. Hasil penelitian ini berupa sebuah website MTs Miftahul Ulum Jragung dan Sistem Informasi Akademik. Pengujian sistem dilakukan dengan metode blackbox dan penilain langsung dari pengguna (Kuisioner).
\end{abstract}

Kata kunci; algoritma sequential search, prototype, sistem informasi akademik

\section{PENDAHULUAN}

Teknologi Informasi dan Komunikasi (TIK) yang ada saat ini sangat memengaruhi perilaku kehidupan masyarakat.Salah satu lembaga yang memanfaatkan TIK ini adalah lembaga pendidikan (sekolah).Teknologi dalam bidang pendidikan meliputi dua bentuk, yakni dalam bentuk perangkat lunak/teknologi sistem (software) seperti; kurikulum, dan perangkat keras/teknologi alat (Hardware) seperti; kertas, bolpoint, papan tulis dll (Syaodih, 1996).

Madrasah Tsanawiyah Miftahul Ulum Jragung merupakan sebuah lembaga pendidikan (setingkat Sekolah Menegah Pertama) yang berada di Desa Jragung Kecamatan Karangawen Kabupaten Demak yang dalam kesehariannya melakukan proses pengelolaan data akademik. Namun demikian, pengelolaan data akademik yang berjalan di MTs Miftahul Ulum sampai dengan penelitian ini di buat masih menggunakan pengelolaan manual yang nantinya akan menjadi permasalahan terkait dengan banyaknya data yang akan di kelola. Salah satu jalan yang dapat ditempuh untuk mengatasi permasalahan pengolahan data akademik yang terdapat di MTs Miftahul Ulum adalah dengan dibuatnya sistem pengolahan data akademik.
Selanjutnya, untuk mempermudah proses pencarian data sistem juga akan ditambah dengan metode penarian data menggunakan algoritma sequential search. Algoritma ini merupakan algoritma paling sederhana dan mudah di aplikasikan ke dalam sistem. Algoritma ini di fungsikan dalam pencarian data acak yang telah dimasukkan ke dalam sistem di mulai dari awal sampai dengan akhir.

\section{Tujuan}

1. Membuat sebuah website company profile MTs Miftahul Ulum Jragung.

2. Membuat sistem informasi akademik MTs Miftahul Ulum yang dapat online untuk membantu dalam pengelolaan dan penginformasian data akademik di sekolah tersebut.

3. Menerapkan Algoritma pencarian Sequential Search pada sistem untuk membantu proses pencarian data.

\section{Penelitian Terkait}

Dalam menyusun laporan penelitian ini, sedikit banyak penulis mengambil referensi sebagai bahan awal yang berkaitan dengan latar belakang masalah. Adapun referensi penelitian terdahulu yang penulis maksud ialah penelitian yang dilakukan oleh Wina Widiati, Program 
Studi Komputerisasi Akuntansi AMIK BSI Jakarta pada tahun 2014 dengan judul "Sistem Informasi Akademik Pada Sekolah Menengah Atas Widya Nusantara Bekasi”, dan penelitian oleh Seprianus Alfian Tanggela dkk, Program Studi Sistem Informasi Fakultas Teknologi Informasi Universitas Kristen Satya Wacana pada tahun 2013 dengan judul "Perancangan Sistem Informasi Akademik Berbasis Web pada SMA Negeri 1 Wewewa Tengah".

\section{Tinjauan Pustaka}

\section{Konsep Sistem Informasi Akademik}

Sistem adalah sekumpulan elemen yang dalam sebuah jaringan yang bekerja secara teratur dalam satu kesatuan yang bulat dan terpadu untuk mencapai sebuah tujuan atau sasaran tertentu (Dengen dan Hatta, 2009).Informasi merupakan sejumlah data yang sudah diolah atau diproses melalui prosedur pengolahan data dalam rangka menguji tingkat kebenarannya, keterpakaiannya sesuai dengan kebutuhan (Darmawan, 2012).Sistem informasi adalah suatu kumpulan dari komponenkomponen yang saling berinteraksi untuk mengelola informasi pada suatu organisasi untuk mendukung kegiatan bisnis organisasi (Shalahuddin dan Rosa, 2008).Sistem informasi akademik adalah sistem yang memberikan layanan informasi yang berupa data dalam hal yang berhubungan dengan data akademik (Setiyawan, 2013).

\section{Konsep Dasar Sekolah}

Sekolah adalah bangunan atau lembaga yang digunakan untuk kegiatan belajar dan mengajar (KBM) serta tempat menerima dan memberi pelajaran. Kurikulum adalah perangkat mata pelajaran yang diajarkan pada lembaga pendidikan.Sementara itu cakupan kurikulum sendiri berisi kurikulum yang berisikan uraian bidang studi/mata pelajaran yang terdiri dari beberapa macam mata pelajaran yang disajikan secara kait-berkait. Kurikulum 2013 adalah kurikulum pengganti dari kurikulum sebelumnya yakni Kurikulum Tingkat Satuan Pendidikan (KTSP) yang dianggap sudah tidak relevan dengan erubahan situasi dan kondisi yang ada di negara Indonesia saat ini.Akademik adalah keadaan dimana orang-orang dapat mengungkapkan dan menerima gagasan, ilmu pengetahuan, dan sekaligus dapat mengujinya secara jujur, terbuka, serta leluasa.

\section{Website}

Website atau situs dapat diartikan sebagai sekumpulan halaman yang memuat informasi data teks, gambar (diam atau bergerak), animasi, suara, video, dan atau gabungan dari semuanya, baik yang bersifat statis maupun dinamis yang membentuk satu rangkaian jaringan informasi yang saling terkait dimana masing-masing dihubungkan dengan jaringan-jaringan halaman (hiperlink).

\section{Konsep Database}

Database (Basisdata) adalah meknisme yang digunakan untuk menyimpan informasi atau data (Stephens dan Plew, 2000).

\section{Alat Bantu Pengembangan Sistem Flowchart}

Flowchart merupakan urutan-urutan langkah kerja suatu proses yang digambarkan dengan menggunakan simbol-simbol yang disusun secara sistematis.

\section{Use case diagram}

Use case diagram merupakan pemodelan untuk melakukan (behavior) sistem informasi yang akan dibuat. Use case endeskripsikan sebuah interaksi antara satu atau lebih aktor dengan sistem informasi yang akan dibuat. Secara kasar, use case digunakan untuk mengetahui fungsi apa saja yang ada didalam sebuah sistem informasi dan siapa saja yang berhak menggunakan fungsi-fungsi itu.

\section{Entity Relationship Diagram}

Entity Relationship Diagram (ERD) adalah sekumpulan cara atau peraturan untuk mendeskripsikan data-data atau objek-objek yang dibuat berdasarkan dan berasal dari dunia nyata yang disebut entitas (Entity) serta hubungan (Relationship) antar entitas-entitas tersebut dengan menggunakan notasi.

\section{Class diagram}

Class diagram adalah untuk menggambarkan struktur sistem dari segi pendefinisian kelas-kelas yang akan dibuat untuk membangun sistem.

\section{Activity diagram}

Activity diagram adalah untuk menggambarkan aliran kerja (workflow) atau aktivitas dari sebuah sistem atau proses bisnis.

\section{Sekuence Diagram}


Diagram sekuen adalah diagram yang menggambarkan kelakuan objek pada use case dengan mendeskripsikan waktu hidup objek dengan pesan yang dikirim bersamaan dengan pesan yang diterima antar objek.

\section{Data Flow Diagram}

Data Flow Diagram menggambarkan arus data didalam sistem dengan terstruktur dan jelas.

\section{Metode Prototype}

Metode prototype dapat dijelaskan dengan Gambar 1.

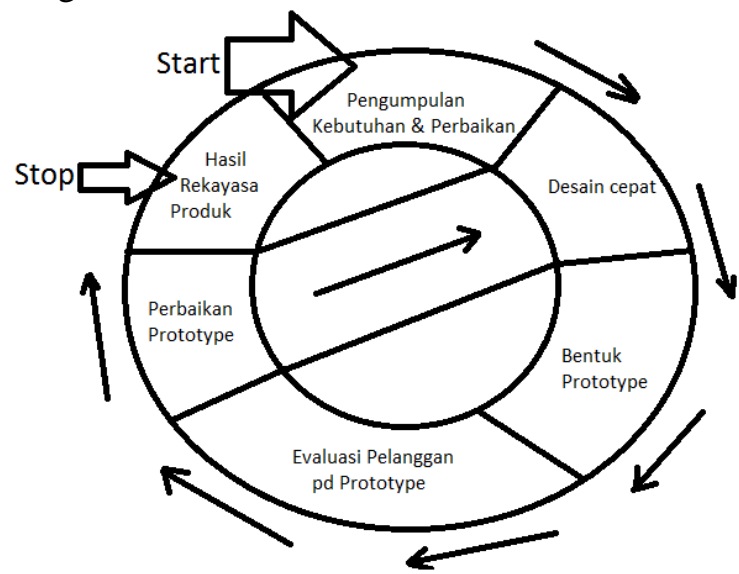

Gambar 1Siklus Prototype

1. Analisis Kebutuhan Piranti Lunak (Software Requarement Analist)

2. perancangan (Design)

3. Bentuk Prototype

4. Evaluasi

5. Perbaikan Prototype

6. Hasil Produk

\section{Tinjuan Objek}

Madrasah Tsanawiyah Miftahul Ulum Jragung Karangawen adalah salah satu lembaga pendidikan setingkat Sekolah Menengah Pertama (SMP) yang berada di lingkungan Kecamatan Karangawen Kabupaten Demak, khususnya di Desa Jragung. Di Desa Jragung sendiri setidaknya ada 3 (tiga) lembaga pendidikan setingkat SMP, dan MTs Miftahul Ulum merupakan lembaga pendidikan setingkat SMP tertua yang berada di Desa Jragung. Sampai tahun 2017 ini MTs Miftahul Ulum setidaknya telah memiliki sebanyak 29 angkatan.

MTs Miftahul Ulum ini memiliki dua tokoh kharismatik yang memiliki andil yang sangat besar sihingga membuat MTs Miftahul Ulum semakin berkembang yakni; KH. M. Marwan, AH., dan K. M. Mahalli. Kedua tokoh ini merupakan pengasuh di masa awal berdirinya MTs Miftahul Ulum.

\section{METODE \\ Metode Pengumpulan Data}

Beberapa teknik pengumpulan data yang digunakan dalam perancangan penelitian ini adalah:

1. Observasi

2. Studi Pustaka

3. Wawancara

4. Kuisioner

\section{Metode Prototype}

Analisis

1. Analisis Hak Akses (admin, staff, siswa, pengunjung)

2. Analisis kebutuhan sistem

3. Analisis perangkat keras

4. Analisis perangkat lunak

\section{Desain}

Pada tahap desain ini terdapat beberapa langkah desain yang akan dilakukan, langkah desain tersebut meliputi desain Flowchart, DFD, ERD, Sekuen Diagram, Class Diagram, Activity, Use case Diagram, desain Basisdatadan antar muka (User Interface Design).

\section{Bentuk Prototype}

Proses pembentukan Prototype Sistem Informasi Akademik ini merupakan proses yang berupa proses Coding (penyusunan program) sistem berdasarkan analisis yang telah ditentukan.

\section{Evaluasi}

Evaluasi ini dilakukan dengan dua langkah yakni; Uji sistem dan kuisioner.

1. Uji Sistem (blackbox)

Dilakukan pengetesan langsung terhadap sistem yang telah dibuat oleh orang yang dianggap mampu dan terbiasa dengan proses pembuatan sistem informasi akademik untuk mengetahui kesesuaian sistem berdasarkan rencana pembuatan.

2. Kuisioner

Dilakukan pertanyaan terhadap koresponden yang berasal dari user pengguna baik dari pengguna umum maupun pengguna administrator terkait dengan pandangan pengguna mengenai 
kinerja sistem, tampilan sistem, kemudahan penggunaan sistem.

\section{Perbaikan}

Perbaikan prototype ini di maksudkan untuk melakukan penambahan atau untuk memperbaiki hasil prototype yang sebelumnya yang dirasa masih kurang sesuai dengan rancangan awal.

\section{Program Rekayasa}

Program rekayasa merupakan hasil jadi setelah sistem dibuat dan disesuaikan dengan kebutuhan awal, serta telah mampu menjawab semua kebutuhan pengguna untuk selanjutnya dilakukan implementasi dan juga perawatan.

\section{HASIL DAN PEMBAHASAN}

\section{User Interface}

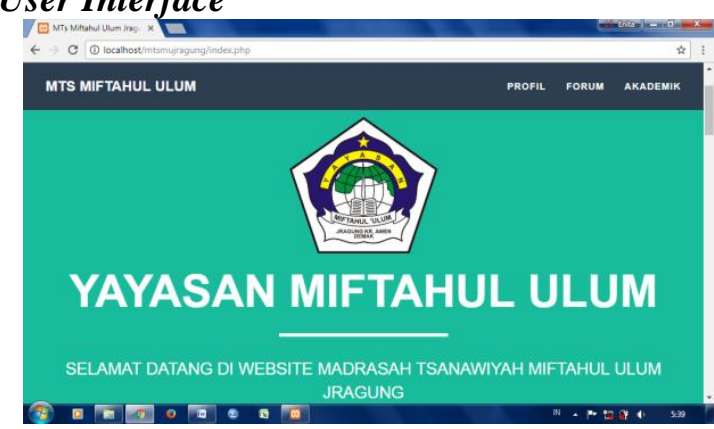

Gambar 2 halaman utama website

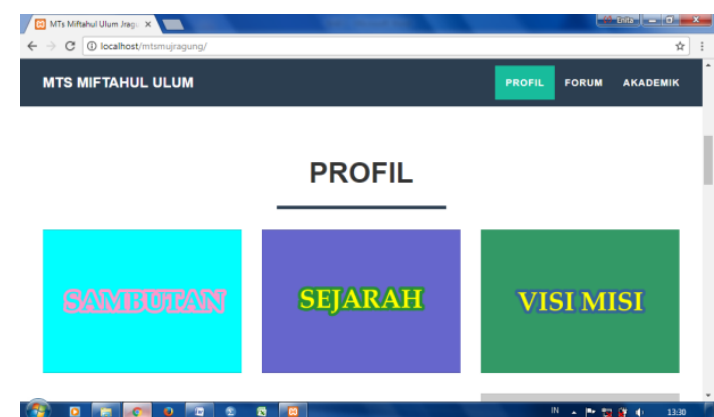

Gambar 3 halaman profil

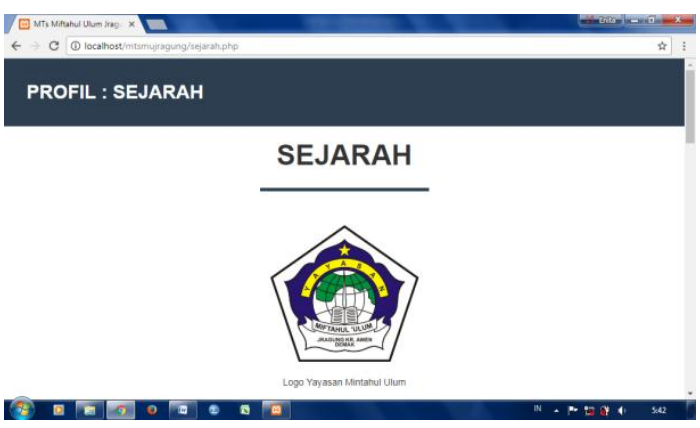

Gambar 4 salah satu halaman isi profil

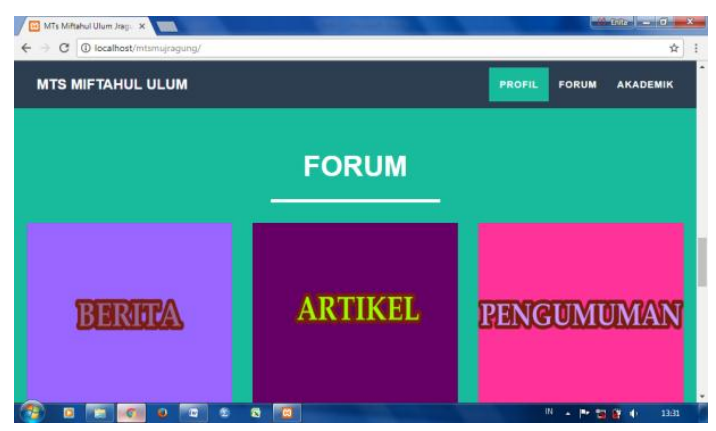

\section{Gambar 5 halaman forum}
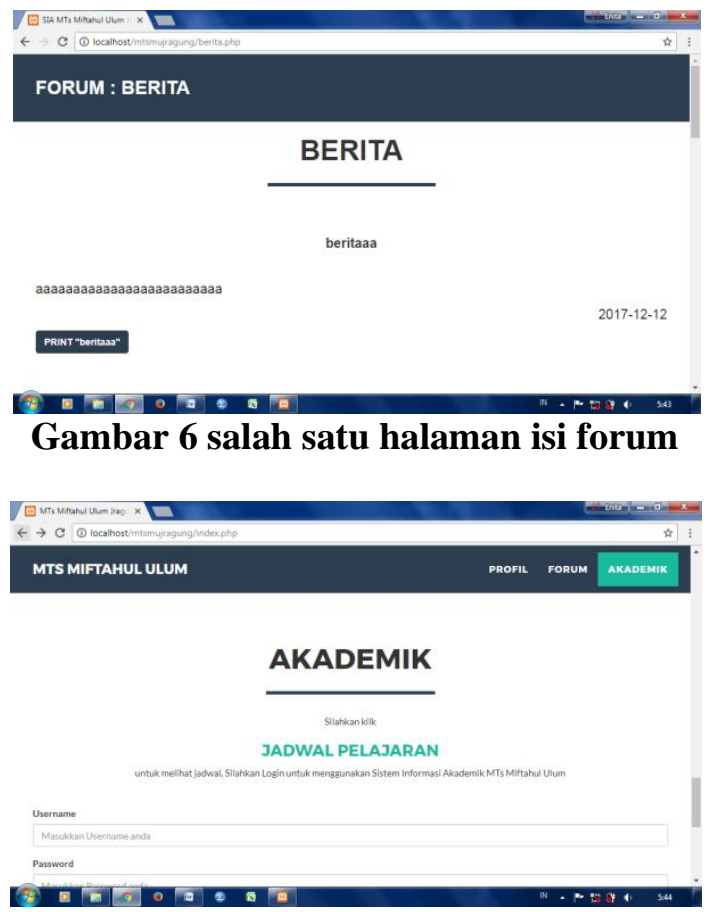

Gambar 7 halaman akademik

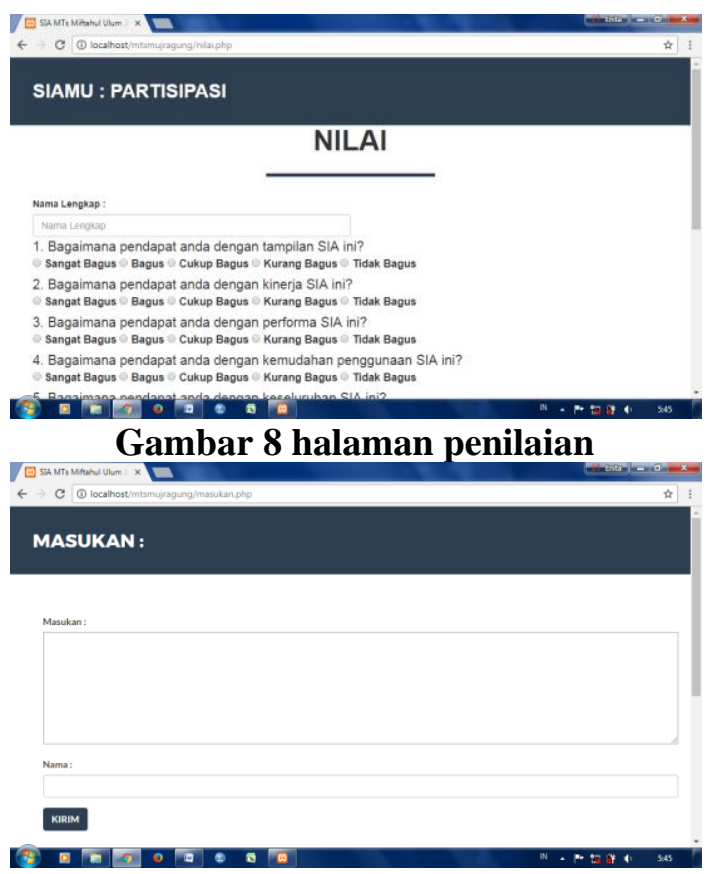

Gambar 9 halaman masukan 


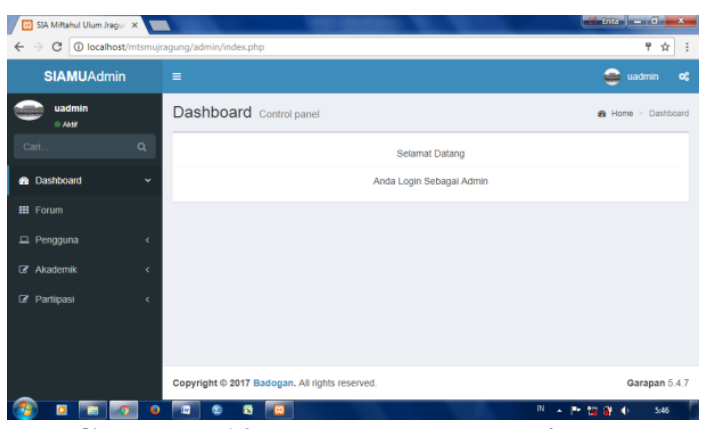

Gambar 10 halaman utama sistem

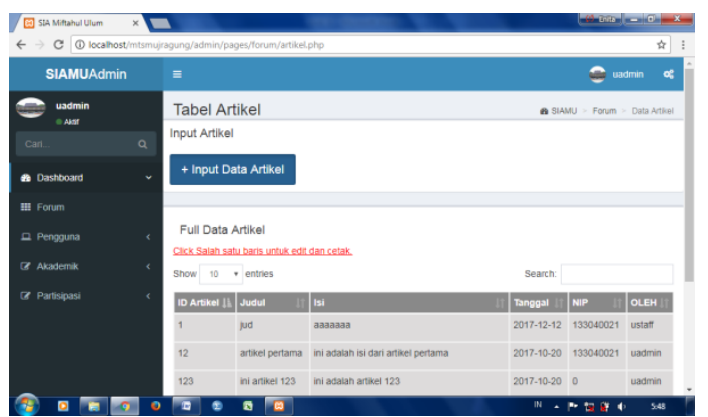

Gambar .11 halaman salah satu menu pada sistem

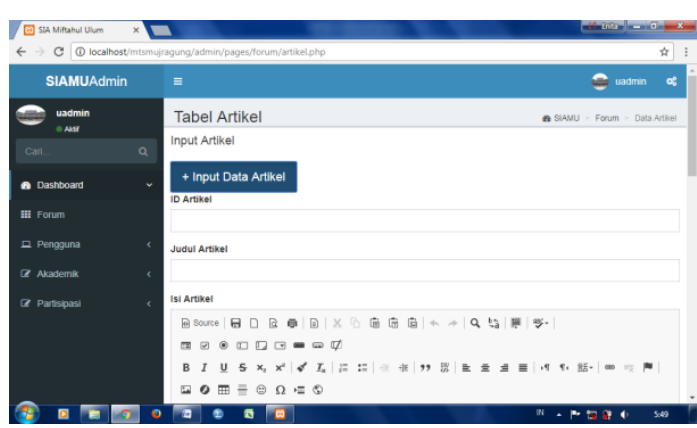

Gambar 12 halaman input data salah satu menu pada sistem

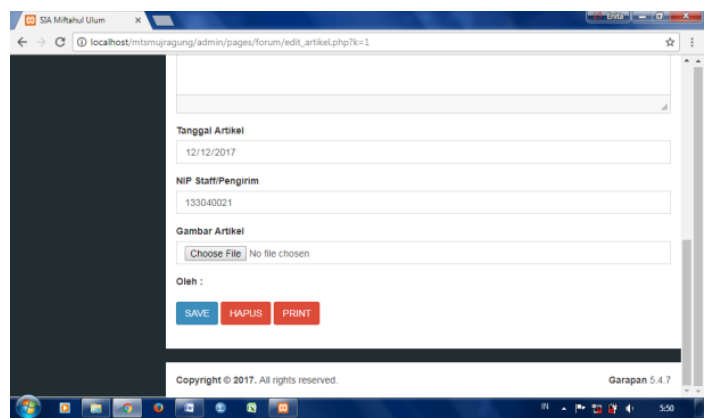

Gambar 13 halaman edit data salah satu menu pada sistem

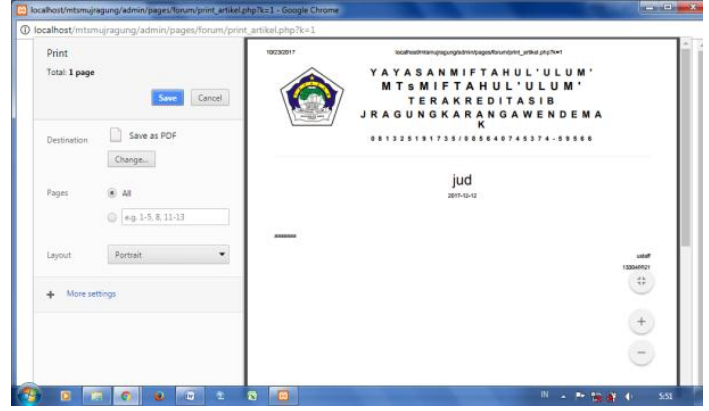

Gambar 14 halaman print sistem

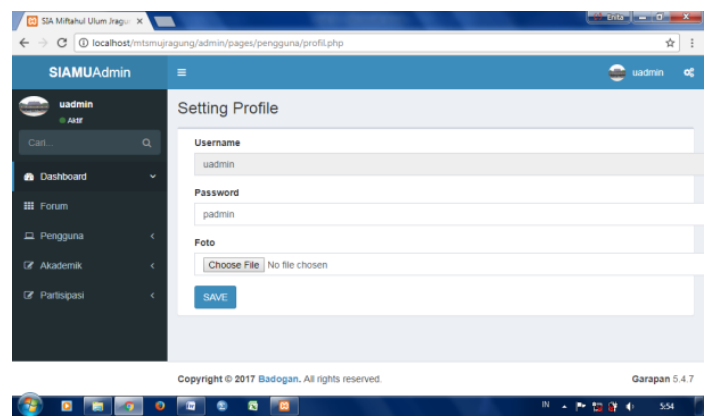

Gambar 15 halaman edit profil sistem

Tabel 1 Pengujian Blackbox

\begin{tabular}{|l|l|c|}
\hline No. & \multicolumn{1}{|c|}{ Parameter Pengujian } & Hasil \\
\hline 1. & $\begin{array}{l}\text { Apakah website dapat berhasil } \\
\text { dibuat ? }\end{array}$ & $\mathrm{Y}$ \\
\hline 2. & $\begin{array}{l}\text { Apakah website bisa login } \\
\text { admin, staff siswa? }\end{array}$ & $\mathrm{Y}$ \\
\hline 3. & $\begin{array}{l}\text { Apakah admin bisa input, edit } \\
\text { hapus dan cetak pada menu } \\
\text { forum (artikel, berita, } \\
\text { pengumuman), pengguna } \\
\text { (siswa, staff), akademik } \\
\text { (jadwal, mapel, nilai, ruang)? }\end{array}$ & $\mathrm{Y}$ \\
\hline 4. & $\begin{array}{l}\text { Apakah admin bisa melihat } \\
\text { penilaian sistem dan masukan } \\
\text { sistem? }\end{array}$ & $\mathrm{Y}$ \\
\hline 5. & $\begin{array}{l}\text { Apakah admin dapat edit } \\
\text { profil? }\end{array}$ & $\mathrm{Y}$ \\
\hline 6. & $\begin{array}{l}\text { Apakah siswa dapat input edit, } \\
\text { hapus cetak data forumnya? }\end{array}$ & $\mathrm{Y}$ \\
\hline 7. & $\begin{array}{l}\text { Apakah staff bisa melihat } \\
\text { jadwal, mapel dan input data } \\
\text { nilai? }\end{array}$ & $\mathrm{Y}$ \\
\hline 8. & Apakah staff bisa edit profil? & $\mathrm{Y}$ \\
\hline 9. & $\begin{array}{l}\text { Apakah siswa bisa melihat dan } \\
\text { mencetak informasi/data } \\
\text { artikel, berita, pengumuman, } \\
\text { jadwal, mapel, nilai? }\end{array}$ & $\mathrm{Y}$ \\
\hline 10. & Apakah siswa bisa edit profil? & $\mathrm{Y}$ \\
\hline 11. & $\begin{array}{l}\text { Apakah admin, staff dan siswa } \\
\text { bisa logout sistem? }\end{array}$ & $\mathrm{Y}$ \\
\hline & & \\
\hline
\end{tabular}

Tabel 2. Kuisioner 
1. Staff (10 orang)

\begin{tabular}{|c|c|c|c|c|c|}
\hline $\begin{array}{l}\text { PENIL } \\
\text { AIAN }\end{array}$ & $\begin{array}{l}\text { SAN } \\
\text { GAT } \\
\text { BAG } \\
\text { US }\end{array}$ & $\begin{array}{l}\text { BA } \\
\text { GU } \\
S\end{array}$ & $\begin{array}{l}\mathrm{CU} \\
\mathrm{KU} \\
\mathrm{P}\end{array}$ & $\begin{array}{l}\text { KUR } \\
\text { ANG }\end{array}$ & $\begin{array}{l}\text { TID } \\
\text { AK } \\
\text { BA } \\
\text { GU } \\
\text { S }\end{array}$ \\
\hline $\begin{array}{l}\text { Tampil } \\
\text { an }\end{array}$ & $20 \%$ & $80 \%$ & - & - & - \\
\hline Kinerja & $40 \%$ & $50 \%$ & $10 \%$ & - & -- \\
\hline $\begin{array}{l}\text { Perfor } \\
\text { ma }\end{array}$ & $30 \%$ & 60\& & $10 \%$ & - & - \\
\hline $\begin{array}{l}\text { Kemud } \\
\text { ahan }\end{array}$ & $40 \%$ & $60 \%$ & - & - & - \\
\hline $\begin{array}{l}\text { Keselur } \\
\text { uhan }\end{array}$ & $50 \%$ & $50 \%$ & - & - & - \\
\hline
\end{tabular}

\section{Siswa (30 orang)}

\begin{tabular}{|l|c|c|c|c|c|}
\hline PENIL & $\begin{array}{l}\text { SAN } \\
\text { AIAN } \\
\text { BAG } \\
\text { US }\end{array}$ & $\begin{array}{l}\text { BA } \\
\text { GU }\end{array}$ & $\begin{array}{l}\text { CU } \\
\text { KU } \\
\text { P }\end{array}$ & $\begin{array}{l}\text { KUR } \\
\text { ANG }\end{array}$ & $\begin{array}{l}\text { TID } \\
\text { AK } \\
\text { BA } \\
\text { GU } \\
\text { S }\end{array}$ \\
\hline $\begin{array}{l}\text { Tampil } \\
\text { an }\end{array}$ & $\begin{array}{c}83,3 \\
\%\end{array}$ & $10 \%$ & $\begin{array}{c}0,7 \\
\%\end{array}$ & - & - \\
\hline Kinerja & $\begin{array}{c}53,3 \\
\%\end{array}$ & $\begin{array}{c}46,7 \\
\%\end{array}$ & - & - & - \\
\hline $\begin{array}{l}\text { Perfor } \\
\text { ma }\end{array}$ & $\begin{array}{c}50 \% \\
43,3 \\
\%\end{array}$ & $\begin{array}{c}0,7 \\
\%\end{array}$ & - & - \\
\hline $\begin{array}{l}\text { Kemud } \\
\text { ahan }\end{array}$ & $\begin{array}{c}66,7 \\
\%\end{array}$ & $\begin{array}{c}10 \% \\
23,3 \\
\%\end{array}$ & - & - \\
\hline $\begin{array}{l}\text { Keselur } \\
\text { uhan }\end{array}$ & $\begin{array}{c}73,3 \\
\%\end{array}$ & $\begin{array}{c}26,7 \\
\%\end{array}$ & - & - & - \\
\hline
\end{tabular}

\section{Pembahasan}

Penelitian tugas akhir ini secara umum bertujuan untuk membuat sebuah website Company Profile dan sistem informasi akademik sekolah di Madrasah Tsanawiyah Miftahul ulum Jragung menggunakan metode pengembangan sistem Prototype. Tujuannya adalah untuk membantu dalam proses pengelolaan dan penginformasian data. Di dalam sistem juga di tambah metode pencarian data menggunakan algoritma pencarian sequential search untuk mempermudah pencarian data. Namun, pembuatan website dan SIA ini tidak dimulai dari awal melainkan, desainnya diambil dari template bootstrap freelancer dan AdminLTE.

Hasil yang didapat dari penelitian ini berupa sebuah website Company Profile MTs Miftahul Ulum dan Sistem Informasi Akademik Miftahul Ulum. Pengujian menggunakan pengujian blackbox sistem yang sesuai dengan harapan dan pengujian kuisioner terhadap calon pengguna sistem (Guru dan Siswa) yang menghasilkan nilai prosentase tertinggi oleh guru yaitu; 80\% (Bagus) untuk tampilan, 50\% (Bagus) untuk kinerja, 60\% (Bagus) untuk performa, $60 \%$ (Bagus) untuk Kemudahan, dan $50 \%$ (sangat bagus, bagus) untuk keseluruhan sistem. Serta nilai prosentase tertinggi oleh siswa yaitu; 83,3\% (Sangat Bagus) untuk tampilan, 533\% (Sangat Bagus) untuk kinerja, $50 \%$ (Sangat Bagus) untuk performa, 66,7\% (Sangat Bagus) untuk Kemudahan, dan 73,3\% (sangat bagus) untuk keseluruhan sistem. Sehingga dapat disimpulkan berdasarkan prosentase tertinggi dari kuisioner penilaian sistem oleh guru dan siswa, sistem bernilai BAIK.

\section{KESIMPULAN}

1. Website Company Profile MTs Miftahul Ulum Jragung berhasil di buat. Website tersebut berisi halaman utama, halaman profil MTs dan juga halaman Forum yang berisi hal-hal yang berkaitan dengan kegiatan MTs.

2. Sistem informasi akademik MTs Miftahul ulum Jragung juga berhasil di buat sesuai dengan analisa yang dilakukan.

3. Algoritma sequential search diaplikasikan ke dalam sistem sebagai metode pencari dan penampil data sesuai kriteria data yang di minta setelah data dimasukkan ke dalam sistem.

\subsection{Saran}

1. Halaman website MTs di tambah dengan menu untuk melihat jumlah pengunjung, kalender dan lain sebagainya.

2. Sistem dikembangkan lagi dengan tambahan fasilitas chatting atau tambahan sistem lain (sistem keuangan, sistem inventaris dan lain-lain) agar website lebih berfariasi.

\section{DAFTAR PUSTAKA}

Alfian, dkk, 2013, Perancangan Sistem Informasi Akademik Berbasis Web Pada SMA Negeri 1 Weweha Tengah, Program Studi Sistem Informasi fakultas Teknologi Informasi Universitas Kristen Satya Wacana Salatiga, h.1-17

Darmawan, D., 2012, Pendidikan Teknologi Informasi dan Komunikasi, PT. Remaja Rosdakarya Offset, Bandung. 
Dengen N. \& Heliza RH., 2009, Perancangan Sistem Informasi Terpadu Pemerintah Daerah Kabupaten Paser, Jurnal Informaika Mulawarman vol 4 No. 1 feb 2009 , h.47-54

Shalahuddin M., \& Rosa AS.,2008,Analisis dan Desain Sistem Informasi, Poloteknik Telkom, Bandung.

Widiati, Wina, 2014, Sistem Informasi Akademik pada Sekolah Menengah Atas Widya Nusantara Bekasi, SWABUMI Vol. I No. 1, September 2014 ISSN : 2355-990X, h.1-12 